\title{
PENERAPAN PENDEKATAN CONTEXTUAL TEACHING AND LERNING DALAM PEMBELAJARAN IPS DI SD UNTUK MENINGKATKAN KETERAMPILAN BERPIKIR KRITIS SISWA
}

\author{
Kanda Ruskandi \\ Universitas Pendidikan Indonesia \\ Yuda Ferdian \\ Universitas Pendidikan Indonesia
}

\begin{abstract}
Abstrak: Penelitian ini dilatarbelakangi oleh pemikiran derasnya arus informasi yang masuk ke Indonesia sebagai dampak dari kemajuan di bidang teknologi informasi dan komunikasi yang tidak semuanya semua dengan kepribadian bangsa. Untuk menangkal pengaruh negatif tersebut diperlukan manusia yang dapat menyaring dan menyeleksi melalui kemampuan dan keterampilan berpikir kritis. Berdasarkan kenyataan menunjukkan bahwa keterampilan berpikir kritis siswa khususnya siswa kelas IV SD Negeri Karangtanjung I masih rendah. Hal tersebut terlihat kurang aktifnya para siswa dalam mengikuti proses pembelajaran. Kondisi tersebut tentu saja tidak hanya disebabkan olh faktor siswa semata, akan tetapi mungkin oleh faktor guru yang tidak variatif dalam mengembangkan berbagai pendekatan pembelajaran yang bersifat inovatif. Tujuan yang ingin dicapai dalam penelitian ini adalah untuk mengetahui gambaran mengenai kemampuan guru dalam menerapkan pendekatan contextual teaching ang learning (CTL), keterampilan berpikir kritis siswa, dan hasil belajar siswa dalam pembelajaran IPS. Penelitian menggunakan metode penelitian tindakan kelas (PTK), dengan subjek penelitian adalah guru kelas IV SD Negeri Karangtanjung I dan siswanya berjumlah 30 orang siswa. Instrumen yang digunakan dalam penelitian ini adalah pedoman observasi untuk guru dan siswa, serta tes hasil belajar. Hasil penelitian menunjukkan bahwa penerapan pendekatan CTL dalam pembelajaran IPS di SD Negeri Karangtanjung I Karawang dengan materi pokok kegiatan ekonomi yang berkaitan dengan sumber daya alam selain dapat meningkatkan kemampuan guru dalam menerapkan pendekatan pembelajaran yang inovatif, juga dapat meningkatkan keterampilan berpikir kritis siswa dan hasil belajar.
\end{abstract}

Kata Kunci : Pendekatan Contextual teaching and learning, Keterampilan berpikir kritis, dan IImu Pengetahuan Sosial.

\section{A. PENDAHULUAN}

IPS merupakan salah satu bidang studi yang bertujuan untuk mempersiapkan siswa agar dapat hidup di masyarakat. Salah satu unsur penting dalam kehidupan di masyarakat adalah keterampilan berpikir kritis. Keterampilan berpikir kritis akan muncul pada diri siswa apabila guru dapat membangun interaksi dan komukasi siswa secara aktif pada saat proses pembelajaran. Oleh karena itu guru dituntut untuk menciptakan suasana kelas yang kondusif agar siswa berperan aktif dalam kegiatan pembelajaran. Guru juga harus berperan sebagai fasilitator untuk dapat memotivasi dan membantu mengembangkan keterampilan berpikir kritis siswa dengan cara menerapkan pendekatan pembelajaran yang bersifat inovatif.

Salah satu pendekatan pembelajaraninovatif yang dapat mengembangkan keterampilan berpikir kritis siswa adalah pendekatan CTL. Pendekatan CTL selain dapat memotivasi siswa untuk dapat 
mengaitkan materi pelajaran dengan hal-hal yang bersifat kontekstual, juga merupakan pendekatan pembelajaran yang bersifat meaningfull (bermakna), artinya siswa dituntut untuk dapat mengaitkan antara pengalaman belajar dengan kehidupan nyata sehingga siswa akan lebih mudah memahami materi ajar.

Pendekatan CTL memfasilitasi siswa untuk dapat mengkonstruksi konsep secara mandiri. Melalui landasan konstruktivisme siswa belajar melalui pengalaman dan bukan menghapal. Dengan demikian, keterampilan berpikir kritis siswa akan tumbuh dan berkembang melalui kemampuan bertanya dan berperan aktif dalam kegiatan pembelajaran.

\section{B. KAJIAN TEORITIS}

1. Pendekatan CTL

a. Pengertian

Contextual berasal dari contex yang berarti hubungan, konteks, suasana atau keadaan. Pendekatan CTL dapat diartikan sebagai suatu pendekatan pembelajaran yang berhubungan dengan suasana tertentu.

Menurut Sanjaya ( 2008, hal 102 ) yang dimaksud pendekatan CTL adalah suatu strategi pembelajaran yang menekankan kepada proses keterlibatan siswa secara penuh untuk dapat menemukan materi yang dipelajari dan menghubungkannya dengan situasi yang nyata, sehingga mendorong siswa untuk dapat menerapkannya dalam kehidupannya.

Mulyasa ( 2010, hal 102 ) menyatakan bahwa CTL merupakan konsep pembelajaran yang menekankan pada keterkaitan antara materi pelajaran dengan dunia kehidupan siswa secara nyata, sehingga para siswa mampu menghubungkan dan menerapkan kompetensi hasil belajar dalam kehidupan sehari-hari.

Johnson (2014, hal 58) menyatakan bahwa CTL merupakan sebuah sistem yang merangsang otak untuk menyusun pola-pola yang mewujudkan makna. CTL adalah suatu sistem pengajaran yang cocok dengan otak yang menghasilkan makna dengan menghubungan muatan akademis dengan konteks kehidupan sehari-hari siswa.

Berdasarkan dari beberapa definisi di atas dapat disimpulkan bahwa CTL merupakan pendekatan pembelajaran yang bermakna bagi siswa karena CTL menuntut siswa untuk membangun konsep secara mandiri dengan cara menghubungkan antara konsepyang dipeljari dengan kehidupan nyata berdasarkan pengalamannya, sehingga siswa dituntut untuk dapat berpikir secara kritis dan analitis

\section{b. Komponen pendekatan CTL}

Menurut Sagala ( 2010, hal. 87 ), menyatakan bahwa dalam pelaksanaannya, pembelajaran dengan menggunakan pendekatan CTL terdiri dari : konstruktivisme ( construktivism), bertanya (quuestioning), menemukan (inquiry), masyarakat belajar

learning community ), pemodelan (modeling ), refleksi reflection), dan penilaian sebenarnya ( authentic assessment).

\section{Keterampilan Berpikir Kritis \\ a. Pengertian}

Berpikir kritis merupakan cara berpikir yang masuk dalam tingkatan yang lebih tinggi. Beragam definisi yang dikemukakan oleh para ahli yang berkaitan dengan keterampilan berpikir kritis.

Ennis (Hassoubah 2008, hal. 87), menyatakan bahwa berpikir kritis adalah berpikir secara beralasan dan reflektif dengan menekankan pembuatan keputusan tentang apa yang harus dipercayai atau dilakukan.

Dewey (Fisher 2009, hl. 2) : berpikir kritis sebuah proses aktif untuk memikirkan berbagai hal secara lebih mendalam untuk diri kita, mengajukan berbagai pertanyaan untuk diri kita, menemukan informasi yang relevan untuk diri kita, dan 
seorang pemikir kritis tidak begitu saja menerima informasi dari orang lain secara pasif.

Johnson (214 hal. 183) : berpikir kritis merupakan sebuah proses yang terarah dan jelas yang digunakan dalam kegiatan mental seperti memecahkan masalah, mengambil keputusan, menganalisis asumsi, dan melakukan penelitian ilmiah.

Rosyada (2004 hal. 170) : kemampuan siswa dalam menghimpun berbagai informasi kemudian membuat suatu kesimpulan dari berbagai informasi tersebut.

Fisher (2009 hal. 10) : interpretasi dan evaluasi yang terampil dan aktif terhadap hasil observasi dan komunikasi serta informasi dan argumentasi.

Berdasarkan ari beberapa definisi di atas dapat disimpulkan, bahwa berpikir kritis merupakan keterampilan berpikir tingkat tinggi yang menuntut seseorang berkemampuan dalam menganalisis berbagai informasi secara aktif untuk dapat menafsirkan berdasarkan kemampuannya sendiri.

\section{b. Ciri-ciri Keterampilan Berpikir Kritis}

Menurut Ennis (Susanto 2013

hal. 125) mengidentifikasi ada 12 indikator keterampilan berpikir kritis yang dikelompokkannya ke dalam 5 aktivitas, yakni :

1) Memberikan

penjelasan sederhana pertanyaan, memfokuskan pertanyaan suatu penjelasan atau pernyataan ).

2) Membangun keterampilan dasar ( mempertimbangkan apakah sumber dapat dipercaya atau tidak, dan mempertimbangkan suatu laporan hasil observasi ).

3) Menyimpulkan ( mendeduksi atau mempertimbangkan hasil deduksi, menginduksi mempertimbangkan hasil induksi, dan membuat serta menentukan hasil pertimbangan ).

4) Memberikan penjelasan lanjut ( mengidentifikasi istilah-isilah, definisi dan dimensi, serta mengidentifikasi asumsi ).

5) Mengatur strategi dan teknik ( menentukan tindakan dan berinteraksi dengan orang lain ).

\section{Pendidikan IPS di SD}

a. Pengertian

IImun Pengetahuan Sosial atau lebih dikenal dengan istilah IPS merupakan bidang studi yang diadopsi dari Amerika dengan istilah social studies. IPS merupakan bidang studi yang di dalamnya mengintegrasikan dari berbagai cabang ilmu-ilmu sosial termasuk humaniora dan sain. IPS diberikan di tingkat persekolahan dengan tujuanb untuk mersiapkan siswa menjadi warga negara yang baik (good citizen).

Menurut National Council for Social Studies (NCSS) ( Sapriya, 2014 hal. 10 ) IPS dapat diartikan sebagai kajian terpadu dari ilmu-ilmu sosial dan untuk mengembangkan potensi kewarganegaraan. Pada tingkat persekolahan IPS dikoordinasikan sebagai bahan sistematis dan dibangun di atas beberapa disiplin ilmu antara lain : antropologi, ilmu politik, ekonomi, geograpi, sejarah, hukum, filsafat, psikologi sosial, agama, sosiologi, dan juga mencakup materi yang sesuai dari humaniora, matematika, dan ilmu-ilmu alam.

\section{b. Tujuan Pendidikan IPS di SD}

Pendidikan IPS dikembangkan tiga aspek atau tiga ranah pembelajaran, yaitu aspek pengetahuan (kognitif), keterampilan (psikomotor), dan sikap (afektif). Ketiga aspek ini merupakan acuan yang berorientasi untuk mengembangkan materi, strategi, dan model pembelajaran.

Dalam Kurikulum Tingkat Satuan (KTSP) 2006 (dalam Susanto, 2014, hlm. 149) bahwa tujuan IPS adalah: 1) Mengenal konsep-konsep 
yang berkaitan dengan kehidupan masyarakat dan lingkungannya; (2) Memiliki kemampuan dasar untuk berpikir logis dan kritis, rasa ingin tahu, inkuiri, memecahkan masalah, dan keterampilan dalam kehidupan sosial; (3) Memiliki komitmen dan kesadaran terhadap nilai-nilai sosial dan kemanusiaan; (4) Memiliki kemampuan untuk berkomunikasi, bekerjasama dan berkompetisi dalam masyarakat yang majemuk, ditingkat lokal, nasional dan global.

$$
\text { Sapriya (2014, }
$$

hlm.12)

mengemukakan tujuan IPS di tingkat sekolah pada dasarnya untuk mempersiapkan para siswa sebagai warga negara yang menguasai pengetahuan (knwoledge), keterampilan (skills), sikap dan nilai (attitudes and values) yang dapat digunakan sebagai kemampuan untuk memecahkan masalah pribadi atau masalah sosial serta kemampuan mengambil keputusan dan berpartisispasi dalam berbagai kegiatan kemasyarakataan agar menajdi warga negara yang baik.

Pendidikan IPS di Sekolah Dasar merupakan bidang studi yang mempelajari manusia dalam semua aspek kehidupan dan interaksinya dalam masyarakat. Dengan tujuan untuk mengembangkan potensi siswa agar peka terhadap masalah sosial yang terjadi di masyarakat, memiliki sikap mental posistif terhadap perbaikan segala ketimpangan yang terjadi, dan terampil mengatasi setiap masalah yang terjadi sehari-hari yang menimpa dirinya sendiri maupun yang menimpa masyarakat.

\section{c. Ruang Lingkup Pendidikan IPS}

Manusia dalam konteks sosial demikian luasnya, maka pengajaran IPS di setiap jenjang pendidikan harus dibuat batasan-batasan sesuai dengan kemampuan siswa pada tingkat masing-masing, sehingga ruang lingkup pengajaran IPS pada jenjang pendidikan dasar berbeda dengan jenjang pendidikan menengah, dan juga dengan jenjang pendidikan tinggi.
Pada jenjang pendidikan dasar, ruang lingkup pengajaran IPS dibatasi sampai gejala dan masalah sosial yang dapat dijangkau pada geografi dan sejarah. Terutama gejala dan masalah sosial kehidupan seharihari yang ada di lingkungan sekitar siswa MI/SD, pada jenjang pendidikan menengah, ruang lingkup kajian semakin diperluas. Begitu juga pada jenjang pendidikan tinggi, bobot dan keluasan materi dan kajian semakin dipertajam dengan berbagai pendekatan. Pendekatan interdisipliner atau multi-disipliner dan pendeketan sistem menjadi pilihan yang tepat untuk diterapkan, karena IPS pada jenjang pendidikan tinggi menjadi sarana melatih daya pikir dan daya nalar mahasiswa secara berkesinambungan.

Sebagaimana, telah dikemukakan di atas, bahwa yang dipelajari IPS adalah manusia sebagai anggota masyarakat dalam konteks sosialnya, maka ruang lingkup kajian IPS di Sekolah Dasar yang tercantum dalam kurikulum menurut Depdiknas (dalam Simdik, 2001) meliputi aspekaspek berikut: 1) Manusia, Tempat, dan Lingkungan 2) Waktu, Keberlanjutan, dan Perubahan, 3) Sistem Sosial dan Budaya, 4) Perilaku Ekonomi dan Kesejahteraan.

\section{METODE PENELITIAN}

1. Lokasi dan Subjek Penelitian

Lokasi penelitian adalah Sekolah Dasar Negeri Karangtanjung 1 Kecamatan Lemahabang Kabupaten Karawang, sedangkan subjek penelitiannya ialah guru kelas IV dan 30 orang siswa kelas IV SDN Karangtanjung.

\section{Jenis Penelitian}

Jenis penelitian yang digunakan dalam penelitian ini adalah penelitian tindakan kelas (Classroom Action Research), karena penelitian ini bersifat melakukan perbaikan pembelajaran. Wiriatmadja (2009, hlm.12) mengemukakan bahwa "penelitian tindakan kelas adalah bagaimana sekelompok guru dapat 
mengorganisasikan kondisi praktek pembelajaran mereka, dan belajar dari pengalaman mereka sendiri".

\section{Desain Penelitian}

Desain penelitian yang digunakan adalah model penelitian tindakan kelas (PTK) yang dikembangkan oleh Stephen Kemmis dan Robin Mc Taggart. Model penelitian tindakan kelas (PTK) ini terdiri dari empat fase, yaitu perencanaan (plan), tindakan (act), pengamatan (observe), dan refleksi (reflect).

\section{Instrumen Penelitian}

Instrumen penelitian

merupakan alat bantu pada waktu peneliti mengumpulkan data. Adapun instrumen penelitian yang digunakan pada penelitian ini adalah sebagai berikut:

\section{a. Tes Hasil Belajar}

Data yang dihimpun dalam penelitian ini adalah hasil evaluasi berupa tes yang berbentuk nilai yang didapat oleh siswa kelas IV yang dijadikan subjek penelitian. Adapun bentuk evaluasinya melalui tes formatif, yaitu tes yang dilakukan pada setiap akhir pembelajaran. Hasil tes awal menggambarkan kemampuan siswa sebelum diterapkan pendekatan CTL, sedangkan tes akhir menggunakan hasil belajar siswa setelah diterapkan pendekatan CTL. Kriteria penliaian untuk setiap butir soal, dilakukan berdasarkan ramburambu yang telah disusun, yaitu dengan memberikan skor 20 untuk setiap jawaban yang benar, skor 10 untuk sebagian jawaban yang benar dan skor 0 untuk jawaban yang salah.

\section{b. Instrumen Non tes}

\section{1) Lembar Observasi}

dilakukan untuk melakuakn pengumpulan data aktivitas guru dan data aktivitas belajar siswa selama proses pembelajaran.

\section{2) Aktivitas Belajar Siswa}

Kegiatan observasi yang dilakukan terhadap aktivitas belajar siswa difokuskan kepada kemampuan berpikir kritisnya. Adapun indikator kemampuan berpikir kritis siswa yang diamati adalah 1). Keterampilan mengidentifikasi atau merumuskan pertanyaan, 2). Keterampilan menjawab pertanyaan, 3). Keterampilan menyampaikan ide atau gagasan, dan 4). Keterampilan menarik kesimpulan sesuai fakta.

\section{3) Aktivitas Guru}

Yang dimaksud dengan aktivitas guru dalam penelitian ini adalah keterampilan guru dalam mengelola kegiatan pembelajaran dengan menggunakan CTL. Adapun aktivitas guru yang diamati terdiri dari 1). Kegiatan pendahuluan: a). Membuka pelajaran, b). Mengkondisikan kelas pada situasi belajar, c). Mengecek kehadiran siswa, d). Mengadakan apersepsi, e). Menyampaikan tujuan pembelajaran, f). Membagi kelompok secara heterogen, 2). Kegiatan inti: Tahap kontruktivisme: siswa diminta untuk menyebutkan yang mereka alami, ketahui, dan dapatkan mengenai materi aktivitas ekonomi yang berkaitan dengan sumber daya alam, 3). Tahap Inquiri: Guru melibatkan siswa dalam proses pembelajaran guna mengetahui dan mengidentifikasi aktivitas ekonomi yang berkaitan dengan sumber daya alam, 4). Tahap bertanya: a). Guru memberikan bimbingan kepada siswa saat proses diskusi berlangsung, b). Siswa diberikan motivasi agar aktif dalam pembelajaran dengan mengemukakan pertanyaanpertanyaan, 5). Tahap masyarakat belajar: a). Guru memberikan masalah/soal yang berhubungan dengan materi, b). Menugaskan perwakilan untuk melaporkan hasil diskusi kelompoknya dalam mengidentifikasi aktivitas ekonomi yang berkaitan dengan sumber daya alam yang ada di lingkungan sekitar, c). Menugaskan kelompok yang sedang tidak melaporkan untuk 
menanggapi dengan bertanya dan memberi komentar. 6). Tahap pemodelan: Guru menggunakan alat bantu dalam pembelajaran, 7). Tahap refleksi: Dengan bimbingan guru siswa diminta menyimpulkan mengenai materi yang telah dipelajari, 8). Tahap penelitian autentik: Guru memberikan penilaian untuk pembelajaran yang sedang berlangsung, 9). Kegiatan akhir: a). Guru memberikan kesempatan pada siswa yang ingin bertanya, b). Guru memberikan evaluasi, c). Menutup Pembelajaran.

\section{4) Dokumentasi}

Dokumen berfungsi sebagai penguat data-data yang sudah didapat, yaitu lembar observasi dan catatan lapangan. Dokumen dapat memberi gambaran konkrit, yang termasuk dalam dokumen adalah Rencana Pelaksanaan Pembelajaran (RPP), Lembar Kegiatan Siswa (LKS), tes dan foto.

\section{E. Teknis Analisis Data}

Data yang dianalisis dalam peneltian ini adalah data yang berasal dari tes hasil belajar dan data hasil observasi yang berupa kemampuan guru dalam menerapkan pendekatan CTL dan aktivitas belajar siswa berupa kemampuan berpikir kritisnya.

Teknik analisis data yang digunakan dalam penelitian ini dilakukan secara kuantitatif dan kualitatif. Observasi berupa deskripsi kualitataif sedangakn untuk tes hasil belajar menggunakan teknik analsisi deskripsi kuantitatif.

\section{Analisis data kuantitatif}

Data kuantitatif berupa skor yang diperoleh dari hasil tes belajar siswa dengan materi pokok aktivitas ekonimi yang berkaitan dengan sumber daya alam. Untuk menghitung ketuntasan belajar siswa (individual) yang didapat dari hasil pretes dan postes dapat dihitung dengan menggunakan persamaan yang dikemukakan oleh Trianto (2009, hlm.241) yaitu:
Keterangan:

$$
{ }_{\text {belajar }}^{T_{1}} \mathrm{~KB}=\text { Ketentuan }
$$$$
=\text { Skor yang diperoleh }
$$

siswa

$$
\mathrm{T}_{1}=\text { Skor ideal }
$$

Data tes yang diberikan kepada siswa berupa soal berbentuk isian terdiri dari 5 soal. Kriteria yang digunakan sebagai acuan untuk mengukur keberhasilan tindakan adalah prsentase nilai ketuntasan belajar siswa secara individual dengan nilai $\geq 65$, sedangan secar klasikal mencapai $85 \%$. Rumus yang dijadikan acuan adalah sebagai berikut: Trianto (2009, hlm.241)

$$
\begin{aligned}
& D \underline{Z} \times \mathbb{O} \\
& \text { Keterangan: } \\
& N \text { =Presentase } \\
& \text { ketuntasan belajar klasikal } \\
& \text { telah tuntas belajar } \\
& \text { =Jumlah siswa yang } \\
& =J u m l a h \text { seluruh siswa } \\
& \text { 3,50-4,00 Sangat Baik } \\
& \text { 3,00-3,49 Baik (B) } \\
& \text { 2,50-2,29 Cukup } \\
& \text { 2,00-2,49 Kurang (K) } \\
& \text { 1,00-1,49 Kurang Sekali (KS) }
\end{aligned}
$$

\section{Analisis data kualitatif}

\section{PEMBAHASAN}

Kemampuan guru dalam menerapkan pendekatan CTL dalam pembelajaran IPS. Pada tindakan pertama menunjukkan bahwa kemampuan guru dalam menerapkan pendekatan CTL 2,68 (cukup). Ini berarti bahwa kemampuan guru dalam menerapkan pendekatan CTL belum 
maksimal. Data pada tabel di sedangkan pada tindakan kedua kemampuan guru dalam melaksanakan pembelajaran dengan menggunakan
CTL mendapatkan nilai 3,57 (sangat baik). Artinya guru telah mampu secara baik melaksanakan kegiatan pembelajaran dengan menggunakan pendekatan CTL.

Tabel 4.4

Kemampuan Guru Menerapkan Pendekatan CTL

\begin{tabular}{|c|c|c|}
\hline Siklus & Rata-rata & Keterangan \\
\hline Pertama & 2,68 & Cukup \\
\hline Kedua & 3,57 & Sangat Baik \\
\hline
\end{tabular}

\section{Keterampilan berpikir kritis} siswa, pada siklus pertama menunjukkan bahwa persentase ratarata keterampilan berpikir kritis siswa adalah 2,54 (cukup), sebanyak 19 orang $(63,33 \%)$. Ini berarti bahwa keterampilan berpikir kritis siswa pada tindakan peratama secara keseluruhan belum menunjukkan yang berarti. Sedangkan pada siklus kedua menunjukkan bahwa keterampilan berpikir kritis siswa mencapai rata-rat 3,74 . Ini berarti bahwa keterampilan berpikir kritis siswa sudah baik sekali. Secara individual siswa yang telah mendapatkan nilai sangat baik berjumlah 29 orang $(96,67 \%)$. Perbandingannya dapat dilihat pada diagram di bawah ini

Diagram 4.3

Perbandingan Keterampilan Berpikir Kritis Siswa Tindakan 1 dengan Tindakan Kedua

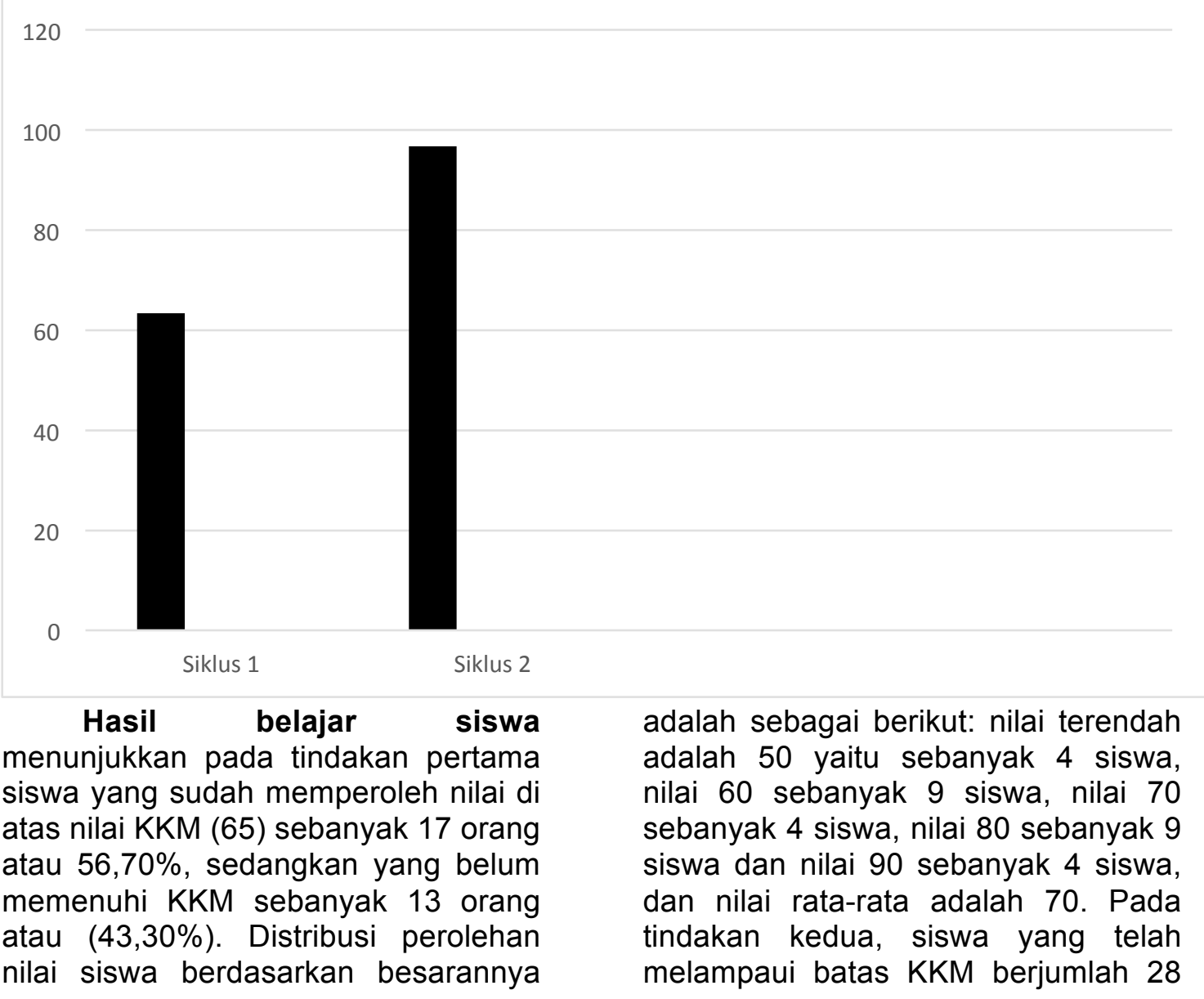


orang atau 93,33\%, sedangakn sisanya berjumlah 2 orang atau $(6,70 \%)$ masih di bawah KKM, dengan nilai rata-rata kelas 86,70 . Rinciannya adalah nilai 50 sebanyak atu orang, nilai 60 satu orang, nilai 70 sebanyak dua orang, nilai 80 sebanyak sembilan orang, nilai 90 sebanyak 7 siswa dan nilai tertinggi yakni 100 sebanyak sepuluh orang.

Tabel 4.15

Kenaikan Frekuensi Nilai Siswa yang Lulus di atas KKM

\begin{tabular}{|c|c|c|c|}
\hline No. & Siklus & Di atas KKM & Persentase \\
\hline 1. & Pertama & 17 & $56,67 \%$ \\
\hline 2. & Kedua & 28 & $93,33 \%$ \\
\hline
\end{tabular}

Perbandingan nilai rata-rata tindakan kedua dapat dilihat pada antara tindakan pertama dengan diagram di bawah ini.

Diagram 4.4

Perbandingan Nilai Rata-rata Siswa Tindakan Pertama dengan Tindakan Kedua

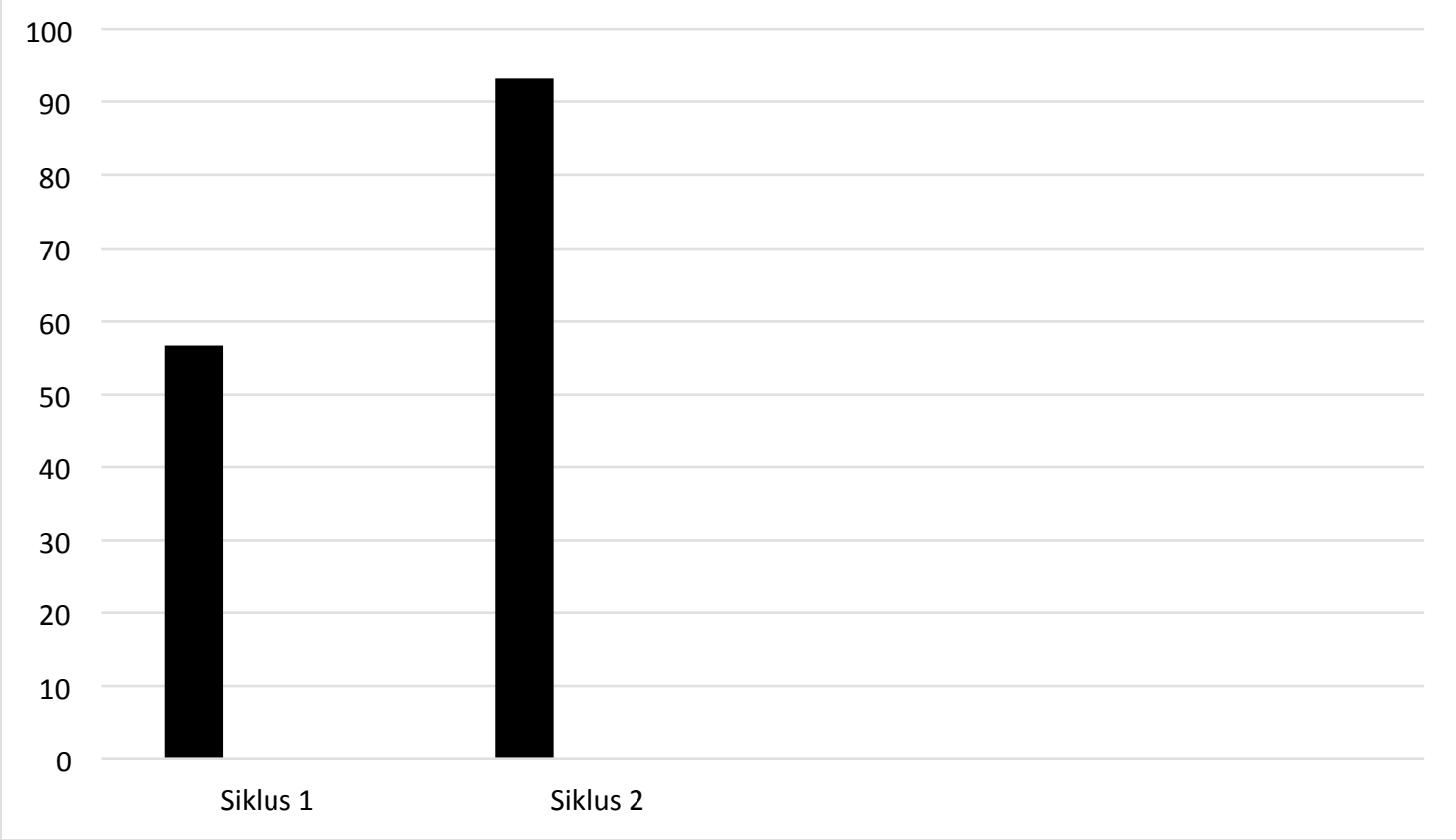

\section{E. KESIMPULAN}

Berdasarkan hasil Penelitian di SDN Karangtanjung 1, dapat disimpulkan sebagai berikut:

Pertama, Kemampuan guru dalam menerapkan pendekatan CTL dalam pembelajaran IPS di Sd setelah dilakukan perbaikan meningkat sangat signifikan. Hal ini dapat dilihat pada tindakan pertama nilai rata-rata kemampuan guru mencapai 2,68 (cukup) menjadi 3,57 (sangat baik) pada tindakan kedua.

Kedua, Keterampilan berpikir kritis siswa meningkat sangat berarti. Hal ini dapat dilihat pada tindakan pertama persentase rata-rata keterampilan berpikir kritis siswa adalah 2,54 (cukup) menjadi 3,74 (sangat baik) pada tindakan kedua.

Ketiga, Hasil belajar siswa meningkat sangat baik. Hal ini dapat dilihat dari data pada tindakan pertama siswa yang sudah memperoleh nilai di atas nilai KKM sebanyak 13 orang atau (43,33\%), dan pada tindakan kedua menjadi 28 orang atau (93,33\%). Ini berarti bahwa penerapan pendekatan CTL dalam pembelajaran IPS tidak hanya berpengaruh terhadap keterampilan 
kritis saja tetapi berpengaruh juga terhadap hasil belajar siswa.

\section{F. DAFTAR PUSTAKA}

Arikunto, S. (2013) Prosedur Penelitian, Jakarta: Rineka Cipta.

Fisher, A. (2009) Developing Creatif and Critical Thinking Skill. (Bambang Suryadi. Terjemahan). Bandung Nuansa. Buku asli diterbitkan tahun 2002.

Johnson, E.B. (2012) Contextual Teaching \& Learning Menjadikan Kegiatan Belajar- Mengajar Mengasyikkan dan Bermakna. Bandung: Mizan Media Utama.

Mulyasa, E. (2010) Menjadi Guru Profesional, Bandung: Remaja Rosdakarya.

Muslich, M. (2007) KTSP Pembelajaran Berbasis Kompetensi dan Kontekstual. Jakarta: PT Bumi Aksara.

Rosyada, D. (2004) Paradigma Pendidikan Demokratis. Jakarta: Prenada Media.

Sagala, S. (2010) Konsep dan Makna Pembelajaran. Bandung: Alfabeta.

Sanjaya, W. (2008) Strategi Pembelajaran Berorientasi Standar Proses Pendidikan. Jakarta: Kencana

Sapriya. (2014) Pendidikan IPS. Bandung: Remaja Rosdakarya

Wiriatmadja, R. (2009) Metode Penelitian Tindakan Kelas. Bandung: Remaja Rosdakarya. 